\title{
Nuclear $\beta$-catenin accumulation is associated with increased expression of Nanog protein and predicts poor prognosis of non-small cell lung cancer
}

Xi-Qing Li', Xing-Long Yang ${ }^{1}$, Gong Zhang ${ }^{1}$, Si-Pei Wu' ${ }^{1}$ Xu-Bing Deng ${ }^{1}$, Sheng-Jun Xiao ${ }^{2}$, Qiu-Zhen Liu', Kai-Tai Yao ${ }^{1 *}$ and Guang-Hui Xiao ${ }^{1 *}$

\begin{abstract}
Background: Although the prognostic roles of $\beta$-catenin expression in non-small cell lung cancer (NSCLC) have been reported in several immunohistochemical (IHC) studies, the results were not consistent because some studies lack sufficient number of the positive cases or did not evaluate the subcellular localization features of the protein.

Method: In this study, we have evaluated the expression levels and subcellular localization of $\beta$-catenin and Nanog proteins IHC staining in tissue specimens from 309 patients with NSCLC, and explored their association with clinicopathological features and patient outcome.

Results: We showed that patients with negative expression of membranous beta-catenin had a trend towards shorter survival ( $p=0.064$ ) than those with positive expression. In contrast to previous studies, we found that increased expression of either cytoplasmic or nuclear $\beta$-catenin was strongly associated with poor prognosis and was an independent prognosticator for overall survival $(p<0.01)$. We further found that NSCLC cells frequently exhibited an abundance of nuclear Nanog protein which was significantly correlated with nuclear $\beta$-catenin expression $(p<0.01)$ and poor prognosis $(p<0.01)$. Interestingly, immunofluorescent staining results revealed that increased expression of Nanog and nuclear translocation of $\beta$-catenin occurred concomitantly in response to epidermal growth factor receptor (EGFR) signaling in A549 and H23 cells. Furthermore, western blot analysis show that nuclear $\beta$-catenin rather than cytoplasmic $\beta$-catenin expression in the A549 and H23 cells can be enhanced by adding EGF, Nanog expression in the A549 and H23 cells with knockdown of $\beta$-catenin can not be obviously enhanced by adding EGF.
\end{abstract}

Conclusion: We propose that evaluation of subcellular localization of $\beta$-catenin and Nanog expression is of clinical significance for patients with NSCLC.

Keywords: $\beta$-catenin, Nanog, Immunohistochemistry, Prognosis, Lung cancer

\section{Introduction}

Lung cancer is the most common cancer worldwide, and has the highest incidence and mortality levels of any cancer [1]. NSCLC is thought to originate in lung epithelial cells, and comprises diverse histological subtypes including adenocarcinoma, bronchioloalveolar, squamous, anaplastic and large-cell carcinomas,

\footnotetext{
* Correspondence: yaokaitai@yahoo.com.cn; ghxiaohh@hotmail.com ${ }^{1}$ Cancer Institute, Southern Medical University, 1023 Shatai Road South, Guangzhou 510515, China

Full list of author information is available at the end of the article
}

and approximately $85 \%$ of lung cancers are identified as NSCLC [2]. Advances in surgical, radiotherapeutic, and chemotherapeutic approaches have been made, but the long-term survival rate remains low [3], with a 5-year overall survival of $9-15 \%$ and a median survival time of 16 to 18 months [4]. The aggressive and heterogeneous nature of lung cancer has thwarted efforts to reduce mortality from the NSCLC. Thus, there is an urgent need for the determination of useful prognostic molecular markers for clinical management of patients with NSCLC.

\section{Ciomed Central}

(c) 2013 Li et al.; licensee BioMed Central Ltd. This is an Open Access article distributed under the terms of the Creative Commons Attribution License (http://creativecommons.org/licenses/by/2.0), which permits unrestricted use, distribution, and reproduction in any medium, provided the original work is properly cited. 
$\beta$-catenin is a key component of the canonical Wnt pathway that plays pivotal roles in pattern formation during embryogenesis and in malignant transformation [5]. At the plasma membrane, $\beta$-catenin is associated with the cadherin class of cell-adhesion proteins and functions in regulating cell adhesion [6]. In the absence of Wnt signal, cytoplasmic $\beta$-catenin interacts with glycogen synthase kinase-3 $\beta$ (GSK-3 $\beta$ ) in a large complex known as destruction complex which also contains the adenomatous polyposis coli (APC) and the axis inhibition protein (Axin). Phosphorylation of $\beta$-catenin at its $\mathrm{N}$-terminus by GSK-3 $\beta$ leads to its degradation via the ubiquitin/proteasome pathway. When Wnt pathway is activated, $\beta$-catenin phosphorylation by GSK-3 $\beta$ is inhibited. The hypophosphorylated $\beta$-catenin is stabilized and translocated to the nucleus, where it binds T-cell factor/lymphoid enhancer factor (TCF/Lef) and activates its target gene expression [7].

Nanog is a core transcription factor required for maintenance of the pluripotency and self-renewal of embryonic stem cells. Nanog protein has been identified as one of four factors essential for reprogramming adult cells into induced pluripotent stem (iPS) cells [8]. Recent studies have revealed that Nanog is also involved in selfrenewal and tumorigenicity of cancer stem cells in a variety of human cancers [9-12]. Increased expression of Nanog protein was observed in a panel of specimens of lung adenocarcinoma and ectopic coexpression of Nanog and another stem cell factor Oct4 enhanced tumorinitiating ability, epithelial-mesenchymal transition, and tumorigenesis in a lung cancer cell line [13].

Nanog is critically involved in regulation of cancer stem cells in several types of tumors [9-12] and has been reported to be target gene of $\beta$-catenin that inhibits differentiation by increasing the expression of Nanog [14]. We also demonstrated Nanog expression could be influenced by $\beta$-catenin in nasopharyngeal carcinoma in our earlier study [15].

In this study, we have evaluated the expression levels and subcellular localization of $\beta$-catenin and Nanog proteins in primary tumor specimens from 309 patients with NSCLC, and explored their association with clinicopathological features and patient outcome.

Table 1 Correlation between the clinicopathologic characteristics and membranous, cytoplasmic and nuclear expression of $\beta$-catenin in 316 NSCLC patients

\begin{tabular}{|c|c|c|c|c|c|c|c|c|c|c|}
\hline \multirow[b]{2}{*}{ Variables } & \multirow[b]{2}{*}{ Cases } & \multicolumn{3}{|c|}{ MEMBRANOUS(n, \%) } & \multicolumn{2}{|c|}{ CYTOPLASMIC(n, \%) } & \multirow[b]{2}{*}{$p^{a}$} & \multicolumn{2}{|c|}{ NUCLEAR(n, \%) } & \multirow[b]{2}{*}{$p^{a}$} \\
\hline & & $\operatorname{Low}(102)$ & $\operatorname{High}(207)$ & $p^{a}$ & $\operatorname{Low}(176)$ & High(133) & & $\operatorname{Low}(170)$ & $\operatorname{High(139)}$ & \\
\hline \multicolumn{11}{|l|}{ Gender } \\
\hline Male & 134 & $42(31.3)$ & $92(68.7)$ & 0.586 & $74(55.2)$ & $60(44.8)$ & 0.590 & $73(54.5)$ & $61(45.5)$ & 0.868 \\
\hline Female & 175 & $60(34.3)$ & $115(65.7)$ & & $102(58.3)$ & $73(41.7)$ & & $97(55.4)$ & $78(44.6)$ & \\
\hline \multicolumn{11}{|l|}{ Age $\left(\right.$ years) ${ }^{b}$} \\
\hline$<52$ & 149 & $59(39.6)$ & $90(60.4)$ & 0.017 & $85(57.0)$ & $64(43.0)$ & 0.976 & $77(51.7)$ & $72(48.3)$ & 0.255 \\
\hline$\geq 52$ & 160 & $43(26.9)$ & 117(73.1) & & $91(56.9)$ & 69(43.1) & & 93(58.1) & 67(41.9) & \\
\hline \multicolumn{11}{|l|}{ Histologic subtype } \\
\hline Squamous carcinoma & 142 & 47(33.1) & $95(66.9)$ & 0.976 & $87(61.3)$ & $55(38.7)$ & 0.158 & $85(59.9)$ & $57(40.1)$ & 0.115 \\
\hline Adenocarcinoma & 167 & $55(32.9)$ & $119(67.1)$ & & $89(53.3)$ & $78(46.7)$ & & $85(50.9)$ & $82(49.1)$ & \\
\hline \multicolumn{11}{|l|}{ Histologicalgrade } \\
\hline Grade 1 & 126 & $34(27.0)$ & $92(73.0)$ & 0.032 & $75(59.5)$ & $51(40.5)$ & 0.644 & $83(65.9)$ & $43(34.1)$ & 0.001 \\
\hline Grade 2 & 112 & $36(32.1)$ & $76(67.9)$ & & $60(53.6)$ & $52(46.4)$ & & $59(52.7)$ & $53(47.3)$ & \\
\hline Grade 3 & 71 & $32(45.1)$ & $39(54.9)$ & & $41(57.7)$ & $30(42.3)$ & & $28(39.4)$ & 43(60.6) & \\
\hline \multicolumn{11}{|l|}{ T classification } \\
\hline $\mathrm{T} 1$ & 71 & $23(32.4)$ & $48(67.6)$ & 0.069 & $43(60.6)$ & $28(39.4)$ & 0.349 & $40(56.3)$ & $31(43.7)$ & 0.727 \\
\hline T2 & 58 & $23(39.7)$ & $35(60.3)$ & & $37(63.8)$ & $21(36.2)$ & & $32(55.2)$ & $26(44.8)$ & \\
\hline T3 & 126 & $39(31.0)$ & $87(69.0)$ & & $70(55.6)$ & $56(44.4)$ & & $72(57.1)$ & $54(42.9)$ & \\
\hline T4 & 54 & $17(31.5)$ & $37(68.5)$ & & $26(48.1)$ & $28(51.9)$ & & $26(48.1)$ & $28(51.9)$ & \\
\hline \multicolumn{11}{|l|}{ Clinical stage } \\
\hline I & 108 & $35(32.4)$ & $73(67.6)$ & 0.818 & $62(57.4)$ & $46(42.6)$ & 0.957 & $56(51.9)$ & $52(48.1)$ & 0.689 \\
\hline II & 81 & $29(35.8)$ & $52(64.2)$ & & $45(55.6)$ & $36(44.4)$ & & $45(55.6)$ & $36(44.4)$ & \\
\hline III & 120 & $38(31.7)$ & $82(68.3)$ & & $69(57.5)$ & $51(42.5)$ & & $69(57.5)$ & $51(42.5)$ & \\
\hline
\end{tabular}

\footnotetext{
a Chi-square test.
}

b Patients were divided according to the median values of age. 


\section{Materials and methods}

\section{Patients and tumor specimens}

Primary tumor specimens from 309 NSCLC patients who underwent curative surgical resection were evaluated in this study. None of these patients had undergone chemotherapy or radiotherapy prior to the surgery. Of these patients, 203 were collected from 2001 to 2005 at Hunan Tumor Hospital and the rest of 96 were from 2002 to 2006 at the Affiliated Hospital of Guilin Medicine University. Patients in the study were examined and treated according to provincial guidelines. This study was approved by the Research Ethics Boards of the Southern Medical University, China.

Cores from formalin-fixed paraffin embedded tumor tissues of NSCLC were arrayed in triplicate onto a tissue microarray (TMA) and each TMA block consisted of up to 40 tissue cores, before the area of cores were chosen, the preliminary experiment of $\beta$-catenin were made to ensure the typical cores. TMAs were constructed using an automated tissue arrayer (Beecher Instruments Inc. USA) by Auragene Bioscience Corporation, China. Tissues core with a diameter of $3 \mathrm{~mm}$ was transferred to a recipient paraffin block (array margin of $15 \mathrm{~mm} \times 20 \mathrm{~mm}$ ). The block was sectioned at a series of $4-\mu \mathrm{m}$-thick slices. Once the TMA slices were made, they were heat $60^{\circ} \mathrm{C}$ for $1 \mathrm{~h}$ to aid cutting.

Relevant clinical pathologic features (Table 1) were obtained from the patients' files and/or by telephone interviews with the patients or their relatives. Pathological stages were classified according to the TNM staging system. Histological grading and typing of the tumor were determined according to the World Health Organization tumor classification system.

\section{Immunohistochemistry (IHC) staining}

Serial tumor sections and IHC staining were used to evaluate both $\beta$-catenin and Nanog proteins. $\beta$-catenin immunoactivity was examined using a mouse polyclonal antibody (Cell Signaling Technology, Danvers). Nanog protein was detected with a rabbit polyclonal antibody (Cell Signaling Technology, Danvers). The TMA blocks containing tissue sections $(4 \mu \mathrm{m})$ were de-waxed in xylene, rehydrated through a graded series of ethanol solutions, rinsed in distilled water for $5 \mathrm{~min}$, and then immersed in boiling citrate buffer in methanol for $1.5 \mathrm{~min}$ for antigen retrieval. After deparaffinization and rehydration, blocks were incubated in $3 \%$ hydrogen peroxide to block endogenous peroxidase activity. Then the sections were subject to immunohistochemistry staining using the primary antibodies overnight at $4^{\circ} \mathrm{C}$ in a humidity chamber. The avidin-biotin technique was applied using DAB for visualization and hematoxylin for nuclear counterstaining. Negative controls were prepared by omitting the primary antibody. Histological and IHC evaluation were independently performed by two pathologists without knowledge of the clinicopathological outcomes of the patients. We classified the IHC staining results into three categories according to subcellular localization of $\beta$-catenin, e.g. membranous, cytoplasmic and nuclear. Briefly, each slide was examined in its entirety under a light microscope, and an initial score was assigned which represented the estimated proportion of positive tumor cells $(0: \leq 5 \% ; 1$ : 5 25\%; 2: 25 75\%; 3: $\geq 75 \%)$. The score 0 was defined as low and 1, 2, 3 as high. Slides with indeterminate evaluation were re-evaluated, and a consensus was reached.

\section{Immunofluorescent staining}

For immunofluorescent staining, A549 [16] or H23 [17] cells grown on the surface of cover slides were serumstarved overnight followed by stimulation with $50 \mathrm{ng} / \mathrm{ml}$ EGF for 24 hours. Cells were fixed with $4 \%$ paraformaldehyde, rehydrated in PBS, and incubated with mouse anti- $\beta$-catenin (Santa Cruz Biotech) and rabbit anti-Nanog primary antibodies (Cell Signaling Technology, Danvers) at room temperature for $40 \mathrm{~min}$. Subsequently, cells were

Table 2 The clinicopathologic characteristics of NANOG expression in 316 NSCLC patients

\begin{tabular}{|c|c|c|c|c|}
\hline \multirow[b]{2}{*}{ Variables } & \multirow[b]{2}{*}{ case } & \multicolumn{3}{|c|}{ NANOG(n, \%) } \\
\hline & & $\operatorname{Low}(215)$ & $\operatorname{High(94)}$ & $p^{a}$ \\
\hline \multicolumn{5}{|l|}{ Gender } \\
\hline Male & 134 & $90(67.2)$ & $44(32.8)$ & \multirow[t]{2}{*}{0.419} \\
\hline Female & 175 & $125(71.4)$ & $50(28.6)$ & \\
\hline \multicolumn{5}{|l|}{ Age (years) ${ }^{b}$} \\
\hline$<52$ & 149 & $99(66.4)$ & $50(33.6)$ & \multirow[t]{2}{*}{0.248} \\
\hline$\geq 52$ & 160 & $116(72.5)$ & $44(27.5)$ & \\
\hline \multicolumn{5}{|l|}{ Histologic subtype } \\
\hline Squamous carcinoma & 142 & $103(72.5)$ & $39(27.5)$ & \multirow[t]{2}{*}{0.298} \\
\hline Adenocarcinoma & 167 & $112(67.1)$ & 55(32.9) & \\
\hline \multicolumn{5}{|l|}{ Histologicalgrade } \\
\hline Grade 1 & 126 & 105(83.3) & 21(16.7) & \multirow[t]{3}{*}{$<0.001$} \\
\hline Grade 2 & 112 & $80(71.4)$ & $32(28.6)$ & \\
\hline Grade 3 & 71 & $30(42.3)$ & $41(57.7)$ & \\
\hline \multicolumn{5}{|l|}{ T classification } \\
\hline $\mathrm{T} 1$ & 71 & $50(70.4)$ & $21(29.6)$ & \multirow[t]{4}{*}{0.572} \\
\hline T2 & 58 & $36(62.1)$ & $22(37.9)$ & \\
\hline T3 & 126 & $91(72.2)$ & $35(27.8)$ & \\
\hline T4 & 54 & $38(70.4)$ & $16(29.6)$ & \\
\hline Clinical stage & & & & 0.358 \\
\hline I & 108 & $75(69.4)$ & $33(30.6)$ & \\
\hline II & 81 & $61(75.3)$ & $20(24.7)$ & \\
\hline III & 120 & $79(65.8)$ & $41(34.2)$ & \\
\hline
\end{tabular}

${ }^{a}$ Chi-square test

${ }^{\mathrm{b}}$ Patients were divided according to the median values of age. 
incubated with Alexa Fluor 488-conjugated anti-rabbit antibody and Alexa Fluor 594-conjugated anti-mouse antibody (Molecular Probes; Invitrogen Corp.) for $40 \mathrm{~min}$ at room temperature. The nuclei were stained with DAPI. Slides were examined with a fluorescent confocal microscope (Olympus FV1000, Japan).

\section{Western blot analysis}

Cytoplasmic and nuclear proteins of A549 and H23 cells were extracted by Nuclear and Cytoplasmic Protein Extraction Kit (Beyotime), then equal amount of protein were subjected to electrophoresis on a SDS-PAGE gel. The separated proteins were transferred to PVDF membranes (Millipore) and probed with appropriate primary antibodies. Protein bands were detected by enhanced chemiluminescence reagents (Pierce Biotechnology).

\section{Lentiviral constructs and infection of NSCLC cells}

Both pLKO.1 lentiviral shRNA vector and control shRNA targeting against GFP were from Aldrich -Sigma. $\beta$-catenin targeting sequences are GCTTGGAATGAGACTGCTG AT, which was previously described in our earlier study [15]. The sense and antisense oligonucleotides were annealed and ligated into pLKO.1 lentiviral vector. The viruses were packaged in 293T cells according to standard protocols. Viral production and infection of target cells were previously described [18]. Infected cells were selected with $2 \mu \mathrm{g} / \mathrm{mL}$ puromycin.

\section{Statistical methods}

Statistical analysis was performed using the SPSS 13.0 software package for Windows. Associations between clinicopathological features and IHC $\beta$-catenin and Nanog

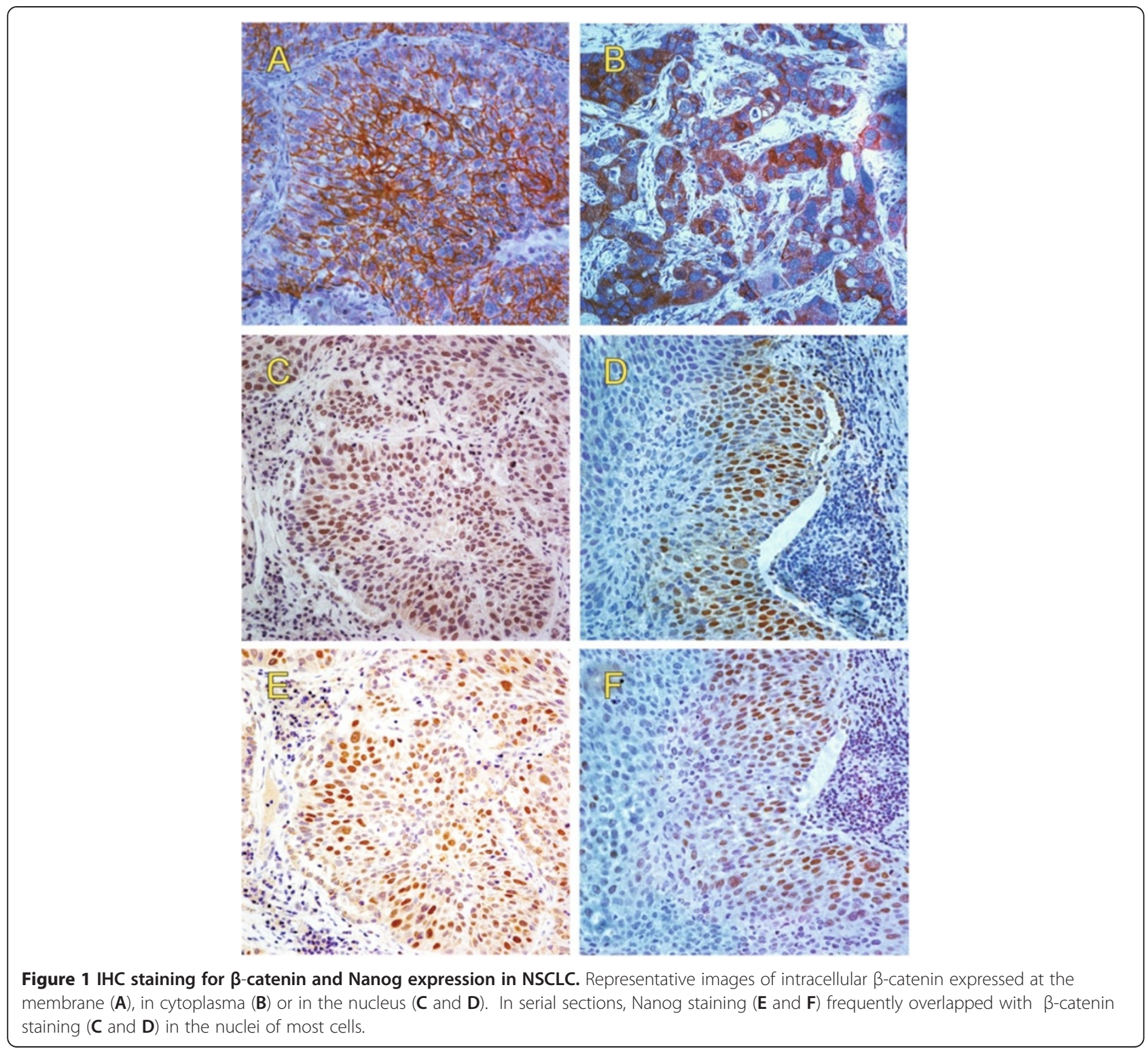


expression were analyzed using the chi-squared test. Multivariate survival analyses were performed with the Cox regression model. Overall survival (OS) was measured from the onset of treatment to the date of death or the survival status at the last date of follow-up. OS probabilities were estimated by the Kaplan-Meier method and the significance of differences was assessed by the logrank test. Correlations between $\beta$-catenin and Nanog expression with clinicopathological factors were analyzed using Fisher's exact probability test or the chi-squared test. A $p$-value $<0.05$ was considered statistically significant.

\section{Results}

\section{Clinicopathological features}

Tumor specimen from 309 NSCLC patients consisting of 134 males and 175 female were included in this study. The median age was 52 years (range: $37-82$ years). Of these patients, 167 (32.9\%) were diagnosed as adenocarcinoma and 142 (33.1\%) diagnosed as squamous carcinoma. Clinical stages, histological grades, and studied proteins were correlated as shown in Table 1. The tumor tissues was classified in three histological grades: grade 1 (126 patients), grade 2 (112 patients) and grade 3 (71 patients). The expression of membranous and nuclear, but not cytoplasmic, $\beta$-catenin expression were correlated with the histological grade $(\mathrm{p}<0.05)$, as shown in Table 1 . Nanog expression that was localized in the nucleus was also correlated with the histological grade $(p<0.01$, Table 2$)$.

\section{Expression of $\beta$-catenin in NSCLC}

Representative images of $\beta$-catenin immunohistochemical staining in NSCLC tissues are shown in Figure 1A-C. Positive membranous, cytoplasmic, and nuclear expression of $\beta$-catenin was detected in 67.0\% (207/309), 43.0\% (133/309), and $45.0 \%$ (139/309) of the NSCLC tissues, respectively.

Nanog is critically involved in regulation of cancer stem cells in several types of tumors and has been reported to be transcriptionally regulated by $\beta$-catenin. Thus we further examined Nanog expression in NSCLC specimen. We found that $30.4 \%$ (94/309) tumor tissues displayed Nanog immunoactivity that was located in the nucleus in most cases (Figure 1D).

\section{Follow-up outcome}

The last follow-up date is Sep. 29th, 2009, with a median follow-up time 52 months (range 7-69.5 months). The 1 -, 3- and 5-year overall survival (OS) rates were $82.4 \%$, $52.5 \%, 30.6 \%$, respectively. The survival rates of 309 NSCLC patients according to status of $\beta$-catenin and Nanog were shown in Table 2. The survival rate of patients with nuclear $\beta$-catenin expression was significantly lower than that of patients without nuclear $\beta$-catenin expression $(p<0.01$, Figure $2 C$ ). Likewise, the survival rate of patients with cytoplasmic $\beta$-catenin expression was significantly lower than that of patients without cytoplasmic $\beta$-catenin expression $(p<0.01$, Figure $2 \mathrm{~B}$ ). However, there was no statistical difference in the survival rate between patients with or without membranous $\beta$-catenin $(p=0.064$, Figure $2 \mathrm{~A})$, but with a trend toward reduced survival in patients with loss of $\beta$-catenin expression. Patients without Nanog protein expression had a significantly better prognosis and longer survival. The overall survival rate was $12.3 \%$ (Nanog-positive) and $38.3 \%$ (Nanog-negative) for this group $(p<0.01)$ (Figure 3$)$.

Univariate analyses showed no significant association between OS and age (>52 yr vs. $\leq 52 \mathrm{yr}$ ), sex (female vs. male), histological subtype (adenocarcinoma vs. squamous carcinoma), T stage (T3-T4 vs. T1-T2), clinical stage (stage III vs. I-II) (Table 3). The expression levels of cytoplasmic and nuclear $\beta$-catenin and Nanog were an independent prognosticator for OS (Table 3). In a multivariate analysis incorporating all clinicopathologic variables and covariates as shown in Table 3, comparisons between genders ages, tumor grades, tumor $\mathrm{T}$ stages, tumor $\mathrm{C}$ stages, expression levels of Nanog protein (low vs. high), and intracellular $\beta$ catenin protein expression at the membrane, in cytoplasm
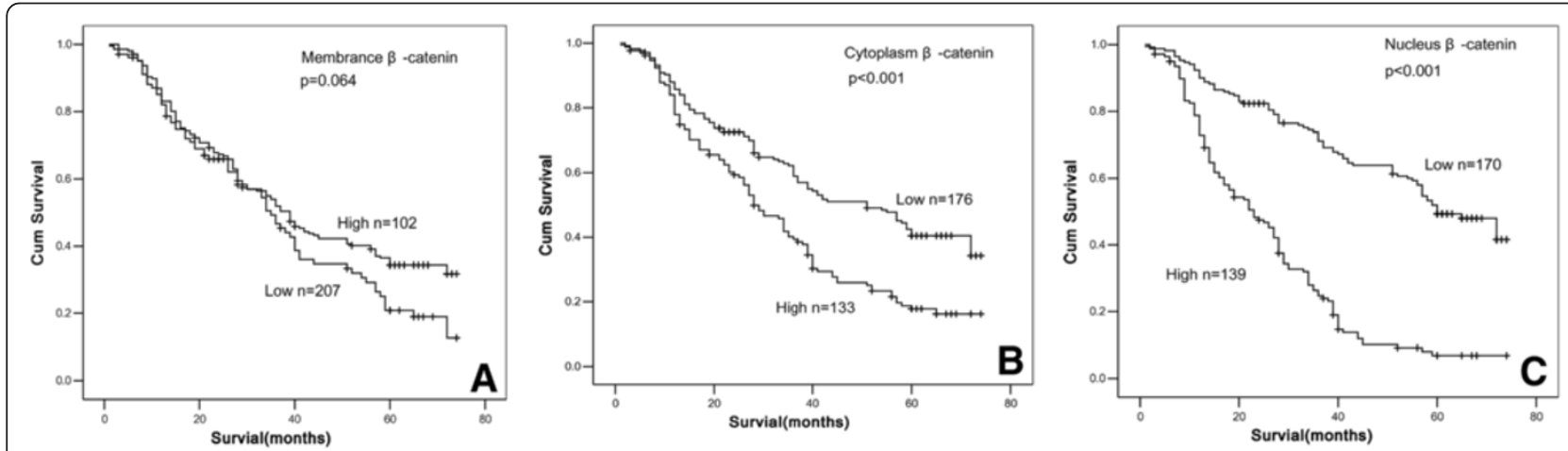

Figure 2 The Kaplan-Meier analysis of survival rate of patients according to status of $\beta$-catenin expression. The influence of membranous (A), cytoplasmic (B), and nuclear (C) $\beta$-catenin expression on the prognosis of patients with NSCLC is shown. 


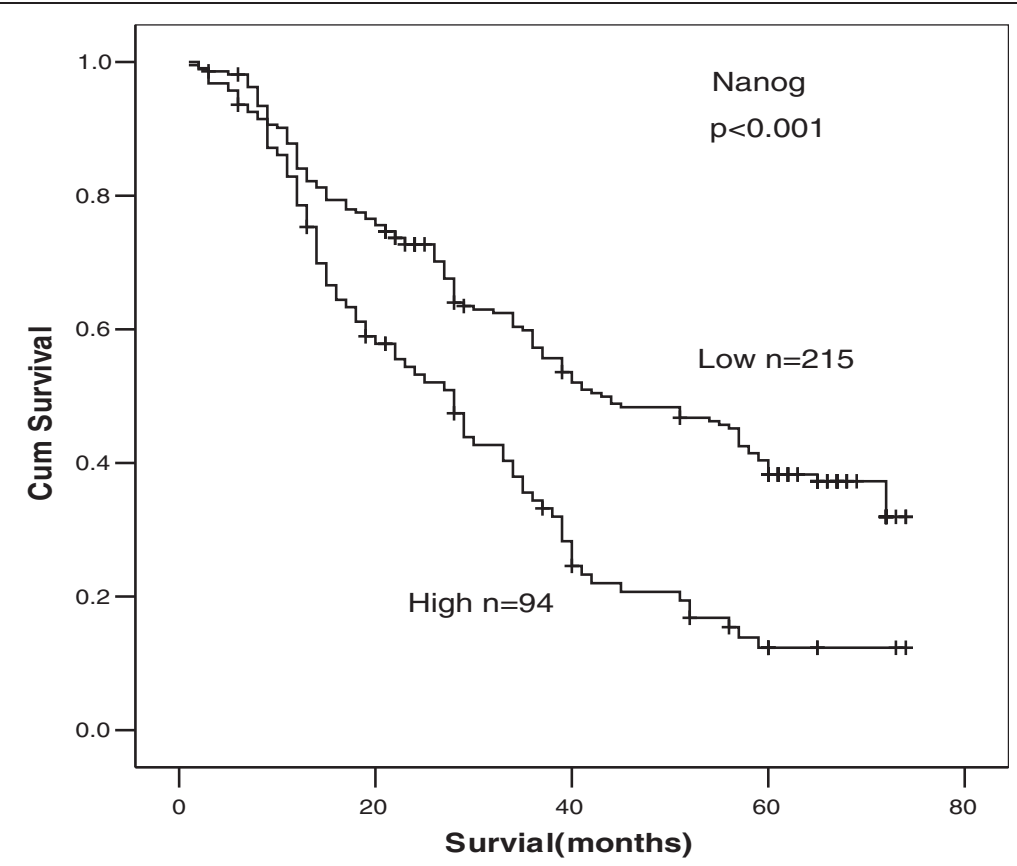

Figure 3 The Kaplan-Meier analysis of survival rate of patients according to status of Nanog expression.

Table 3 Univariate and multivariate analysis for clinicopathologic variables

\begin{tabular}{|c|c|c|c|c|c|c|}
\hline \multirow[b]{2}{*}{ Parameters } & \multicolumn{3}{|c|}{ Univariate analysis } & \multicolumn{3}{|c|}{ Multivariate analysis } \\
\hline & $\mathrm{HR}^{a}$ & $95 \% \mathrm{Cl}^{b}$ & $P^{c}$ & $\mathrm{HR}^{a}$ & $95 \% \mathrm{Cl}^{b}$ & $P^{c}$ \\
\hline \multicolumn{7}{|l|}{ Gender } \\
\hline Male vs. female & 1.032 & $0.782-1.363$ & 0.826 & & & \\
\hline \multicolumn{7}{|l|}{ Age (years) } \\
\hline$<52$ vs. $\geq 52$ & 0.995 & $0.756-1.311$ & 0.948 & & & \\
\hline \multicolumn{7}{|l|}{ Histologic subtype } \\
\hline ad vs I & 1.111 & $0.842-1.466$ & 0.456 & & & \\
\hline \multicolumn{7}{|l|}{ T classification } \\
\hline T1-T2 vs. T3-T4 & 0.956 & $0.832-1.099$ & 0.529 & & & \\
\hline \multicolumn{7}{|l|}{ C classification } \\
\hline I-II vs. III & 0.961 & $0.818-1.129$ & 0.629 & & & \\
\hline \multicolumn{7}{|l|}{ Differention } \\
\hline Grade1,Grade2,Grade3 & 1.520 & $1.272-1.816$ & 0.000 & 1.526 & $1.273-1.829$ & 0.000 \\
\hline \multicolumn{7}{|l|}{ Membranous } \\
\hline positive and negative & 0.763 & $0.571-1.021$ & 0.069 & 0.820 & $0.609-1.106$ & 0.193 \\
\hline \multicolumn{7}{|l|}{ Cytoplasmic } \\
\hline positive and negative & 1.815 & $1.375-2.396$ & 0.000 & 1.871 & $1.412-2.478$ & 0.000 \\
\hline \multicolumn{7}{|l|}{ Nuclear } \\
\hline positive and negative & 3.864 & $2.872-5.200$ & 0.000 & 3.776 & $2.786-5.118$ & 0.000 \\
\hline \multicolumn{7}{|l|}{ Nanog } \\
\hline positive and negative & 1.994 & $1.494-2.661$ & 0.000 & 1.700 & $1.249-2.315$ & 0.001 \\
\hline
\end{tabular}

${ }^{a}$ HR Harzard Rate.

${ }^{\mathrm{b}} \mathrm{Cl}$ Confidence Interval.

${ }^{\mathrm{C}}$ Cox regression model.

The expression levels of cytoplasmic and nuclear $\beta$-catenin and Nanog were an independent prognosticator for overall survive. 
and in the nucleus (low vs. high) were performed to identify independent prognostic factors.

\section{Correlation between $\beta$-catenin and Nanog expression in NSCLC}

We further analyzed correlation between expression status of Nanog and $\beta$-catenin. As mentioned above, positive Nanog protein staining was almost exclusively observed in nucleus and $\beta$-catenin expression was stratified according to its subcellular locations (Table 4). Seventy two of the $139(51.8 \%)$ tumor tissues that stained positive for nuclear $\beta$-catenin also displayed Nanog immunoactivity. Among the 170 specimen without nuclear $\beta$-catenin expression, only $22(12.94 \%)$ showed Nanog immunoreactions (Fig. $4 C, p<0.001$ ). On the contrary, only 55 (26.6\%) of the 207 specimen with membranous $\beta$-catenin expression showed Nanog immunoreactions (Table 4, $p=0.036$ ). Likewise, cytoplasmic $\beta$-catenin expression is not correlated with Nanog protein (Table $4, p=0.166$ ) even though cytoplasmic $\beta$-catenin is associated with poor prognosis. However, expression of cytoplasmic and nuclear $\beta$-catenin is correlated, among the 133 specimen with cytoplasmic $\beta$-catenin expression, 105 (78.9\%) showed nuclear $\beta$-catenin immunoreactions (Table 5, $\mathrm{p}<0.001$ ).

\section{Expression of $\beta$-catenin and Nanog was concomitantly regulated by EGFR signaling}

EGFR signal transduction pathway is critically involved in cell proliferation and survival of tumors of epithelial cell origin [19]. Increased expression of EGFR has been detected in $40 \%-80 \%$ of NSCLC and has been associated with advanced disease and poor prognosis [20]. Recently, we demonstrated that activation of EGFR increased cancer stem-like cell properties in nasopharyngeal carcinoma, and this effect of EGFR was mediated by PI3K/ $\mathrm{AKT} / \beta$-catenin signaling [15]. In the present study, high incident of nuclear $\beta$-catenin was detected in lung cancer specimens and was associated with poor survival. Thus we asked if EGFR signaling could induce $\beta$-catenin activation in NSCLC. For this purpose, serum-starved A549 (Figure 4A) or H23 (Figure 4B) cells were incubated without or with EGF and subjected to immunofluorescent staining. In the absence of EGF, $\beta$-catenin was located predominantly at the plasma membrane, with faint staining distributed in the cytoplasm. When cells were treated with EGF, $\beta$-catenin staining translocated to the nucleus in both A549 and H23 cells. These results suggested that nuclear accumulation of $\beta$-catenin can be induced not only by Wnt signaling, but also by EGF stimulation in NSCLC. In addition, nuclear Nanog expression was dramatically enhanced in response to EGFR activation. These results of in vitro experiments with established cell lines are consistent with our finding that nuclear $\beta$-catenin is significantly
Table 4 Correlation between $\beta$-catenin and Nanog expression

\begin{tabular}{llllll}
\hline & & & \multicolumn{2}{c}{ Nanog } & $p^{a}$ \\
\cline { 3 - 5 } & & & - & \\
\hline Membranous & 102 & - & $63(61.8)$ & $39(38.2)$ & 0.036 \\
& 207 & + & $152(73.4)$ & $55(26.6)$ & \\
Cytoplasmic & 176 & - & $128(72.7)$ & $48(27.3)$ & 0.166 \\
& 133 & + & $87(65.4)$ & $46(34.6)$ & \\
Nuclear & 170 & - & $148(87.1)$ & $22(12.9)$ & $<0.001$ \\
& 139 & + & $67(48.2)$ & $72(51.8)$ & \\
\hline
\end{tabular}

${ }^{\text {a }}$ Chi-square test.

Nanog is significantly associated with membranous or nuclear $\beta$-catenin expression $(p<0.05)$. No statistical correlation exists between cytoplasmic $\beta$-catenin and Nanog proteins $(p=0.166)$.

associated with Nanog expression in primary NSCLC specimens.

Nuclear $\beta$-catenin is requirement in the regulation of Nanog We investigated the requirement of $\beta$-catenin in the regulation of Nanog in A549 and H23. To this end, $\beta$-catenin was knocked down with lentivirus-mediated shRNAs (Figure 5A). Compared with cells infected with the control shRNA lentivirus, cells infected with $\beta$-catenin shRNA lentivirus exhibited reduced Nanog expression. Moreover, Nanog expression in the NSCLC cells with knockdown of $\beta$-catenin can not be obviously enhanced by adding EGF, but on the other hand, when the expression of $\beta$-catenin is increased by adding EGF, Nanog thereupon increased expression upon $\beta$-catenin (Figure $5 \mathrm{~B}$ ). It is worthy of note that nuclear $\beta$-catenin rather than cytoplasm $\beta$-catenin expression in the NSCLC cells can be enhanced by adding EGF, (Figure 5C).

\section{Discussion}

During the past decade, mounting evidence has well demonstrated that accumulation and nuclear localization is a hallmark of $\mathrm{Wnt} / \beta$-catenin pathway activation. In addition to controlling cell-cell adhesion through its binding with cadherin at the membrane, $\beta$-catenin acts as a transcriptional activator in the nucleus where it interacts with LEF1 and TCF transcription factors and regulates transcription of target genes responsible for cell proliferation and

Table 5 Correlation between cytoplasmic and nuclear of $\beta$-catenin expression

\begin{tabular}{lccccc}
\hline & & & \multicolumn{2}{c}{ Nuclear } & $p^{a}$ \\
\cline { 3 - 4 } & & & - & + & \\
\hline Cytoplasmic & 176 & - & $142(80.7)$ & $34(19.3)$ & $<0.001$ \\
& 133 & + & $28(21.1)$ & $105(78.9)$ & \\
\hline
\end{tabular}

${ }^{\text {a }}$ Chi-square test.

Cytoplasmic $\beta$-catenin is significantly associated with Nuclear $\beta$-catenin expression $(p<0.001)$. 

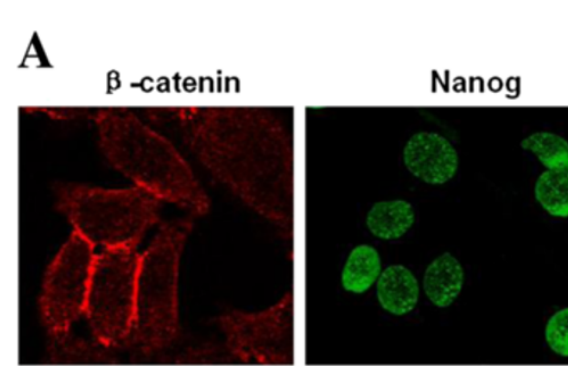

\section{A549}
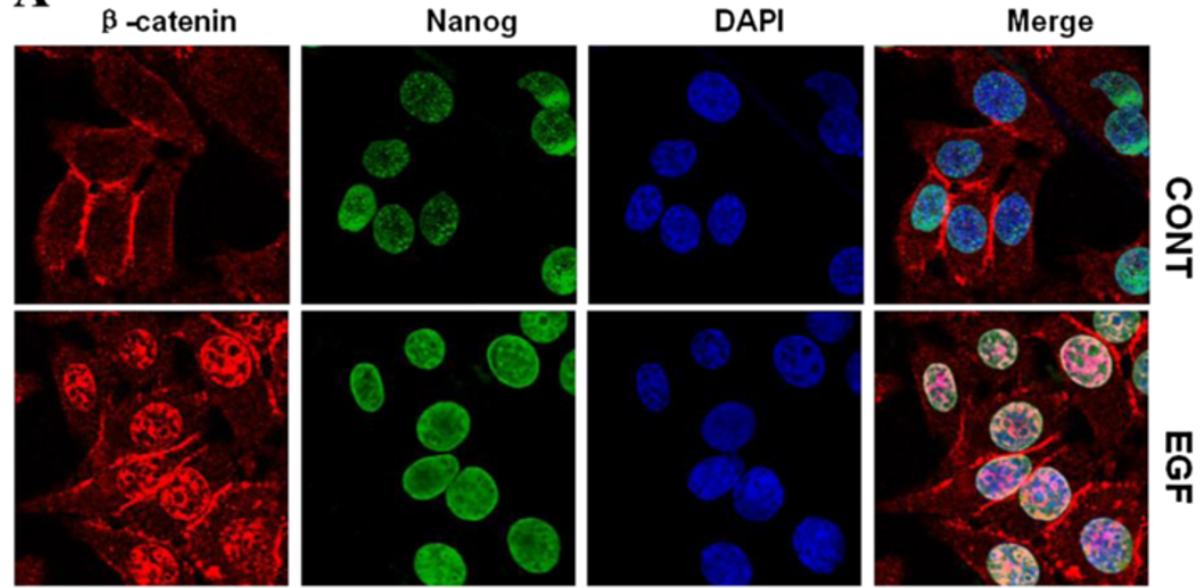

B

H23

$\beta$-catenin
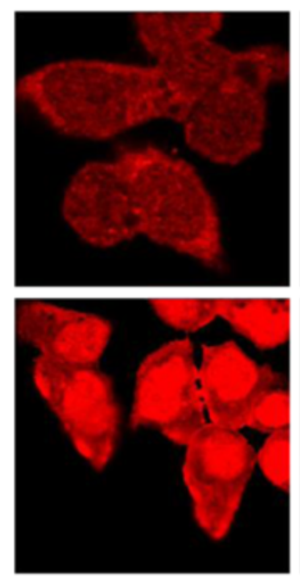

Nanog
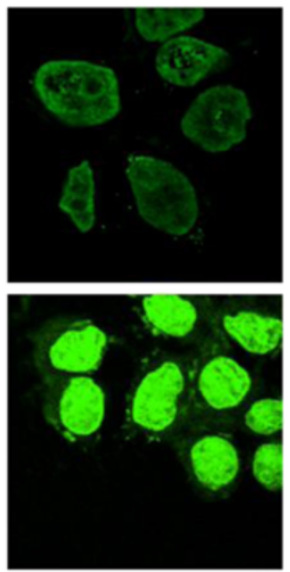

DAPI
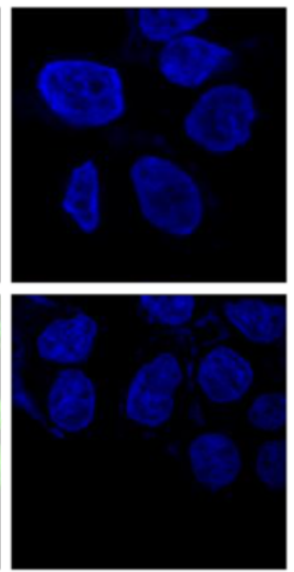

Merge
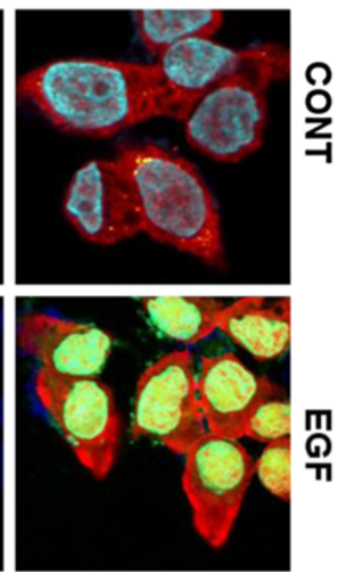

Figure 4 Expression of $\beta$-catenin and Nanog was concomitantly regulated by EGFR signaling. A549 (A) and H23 (B) cells were treated without or with EGF followed by immunofluorescent staining. In the absence of EGF, $\beta$-catenin was located predominantly at the plasma membrane, with faint staining distributed in the cytoplasm. Faint Nanog staining was detected in the nucleus. When cells were treated with EGF, $\beta$-catenin staining translocated to the nucleus in both cell lines and nuclear Nanog staining was moderately increased in A549 cells and abundantly accumulated in $\mathrm{H} 23$ cells.

differentiation. Thus, subcellular localization of $\beta$-catenin from cell membrane to the nucleus determines its two distinct functions. In agreement with these findings, cytoplasmic and nuclear $\beta$-catenin expression has been reported to be associated with a poorer prognosis in patients with cancers of breast, liver, and colon [21-23].

The prognostic roles of $\beta$-catenin expression in NSCLC have been extensively studied in the past years $[24,25]$. In a very recent study reported by Chiu et al. on 370 cases of NSCLC, $\beta$-catenin expression was found to be negative in $28 \%$ of tumors and positive in $72 \%$ of tumors. The lack of $\beta$-catenin expression was significantly associated with poor survival and retained independent prognostic significance [26]. Similar results were also observed in a number of early studies. In the present study, we evaluated the expression of $\beta$-catenin in 309 tissue specimens of NSCLC. In order to more precisely analyze $\mathrm{IHC}$ results in relation to patient prognosis and survival, we have classified the IHC staining results into three categories according to subcellular localization of $\beta$-catenin. We showed that patients with negative expression of membranous $\beta$-catenin had a trend of shorter survival $(p=0.067)$ than those with positive expression. This result is in agreement with the findings reported by others previously.

In addition to the similarity, there are some striking differences between our results and those of earlier studies. We found that increased expression of nuclear 


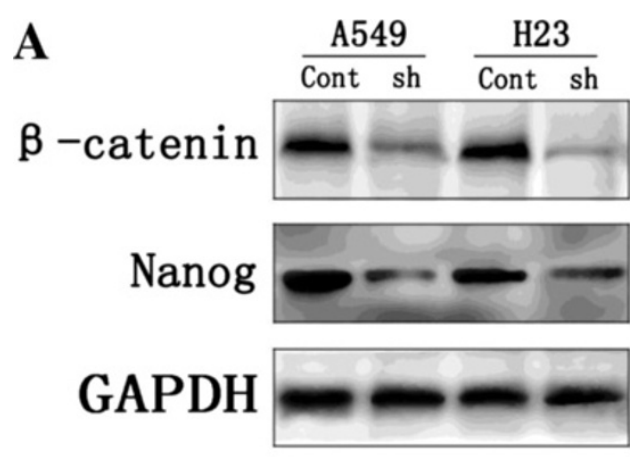

B
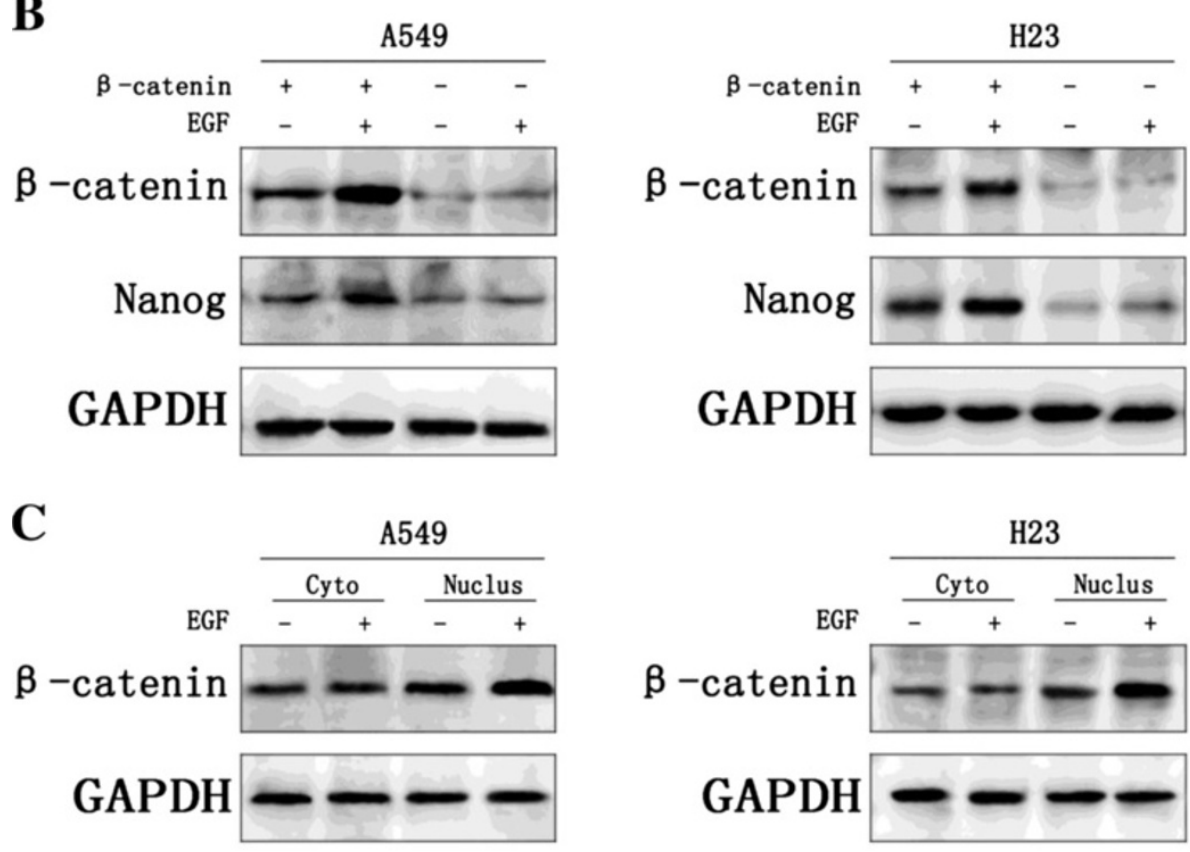

Figure 5 Nuclear $\beta$-catenin is requirement in the regulation of Nanog. A549 cells and H23 cells infected with control shRNA lentivirus(Cont) or $\beta$-catenin shRNA(sh). In both cell lines, $\beta$-catenin protein was markedly knocked down with $\beta$-catenin shRNA. Knockdown of $\beta$-catenin also decreased the Nanog expression. All experiments were carried 3 times independently (Figure 5A). Nanog expression in the A549 and H23 cells with knockdown of $\beta$-catenin can not be obviously enhanced by adding EGF, but on the other hand, when the expression of $\beta$-catenin is increased by adding EGF, Nanog thereupon increased expression upon $\beta$-catenin (Figure 5B). Nuclear $\beta$-catenin(Nucles) rather than cytoplasm $\beta$-catenin(Cyto) expression in the A549 and H23 cells can be enhanced by adding EGF (Figure 5C).

$\beta$-catenin was strongly associated with poor prognosis of patients with NSCLCs. In addition, multivariate analysis revealed that the expression of nuclear $\beta$-catenin was an independent prognosticator for OS. These data are consistent with recent observations that increased $W n t / \beta$-catenin pathway activity is associated with metastasis and relapse in primary lung adenocarcinoma [27]. Importantly, even though we revealed that cytoplasmic $\beta$-catenin was a prognosticator, these observations do not exclude the possibility that nuclear $\beta$-catenin acts primarily on the prognosis, since a majority of cases over expressing cyto-plasmic $\beta$-catenin also contain nuclear $\beta$-catenin expression. We further demonstrated by immunofluorescent staining and/or western blot analysis that independent to Wnt, nuclear accumulation of $\beta$-catenin can be induced by EGFR pathway that is critically involved in tumorigenesis of NSCLC. Our in vitro results provide not only supportive evidence to our IHC finding that nuclear $\beta$-catenin is significantly associated with Nanog expression in primary NSCLC specimens, but also an additional mechanism by which $\beta$-catenin activation is regulated by growth factor signaling in a Wnt-independent manner in NSCLC.

In contrast to our investigation, some earlier studies evaluated only the overall intensity of IHC staining of $\beta$-catenin in tumor cells without stratification of the data based on subcellular localization of the protein. Thus the distinct impact of $\beta$-catenin at different cellular compartments on patient prognosis and survival was ignored. Some of the 
studies $[28,29]$ evaluated cytoplasmic or nuclear $\beta$-catenin specifically, but found no correlation between cytoplasmic or nuclear staining and clinicopathological parameters or survival rates, probably due to low numbers of the positive cases identified in those studies. One of the early study [30] showed that increased expression of cytoplasmic and nuclear $\beta$-catenin can predict favorable prognosis of NSCLCs patients. However, $\beta$-catenin immunoactivity was found to be associated with increased proliferation as suggested by high Ki-67 expression in the same set of specimens.

Nanog protein is elevated in many human tumors including NSCLC and might positively regulate tumor metastasis through enhancing EMT in lung adenocarcinoma [13]. We found that Nanog is expressed in significant portion of specimens and Nanog immunoactivity was observed in the nucleus. Expression of Nanog is significantly correlated with nuclear, but not membranous nor cytoplasmic, $\beta$-catenin. Furthermore, our IHC staining demonstrated that increased expression of Nanog and nuclear translocation of $\beta$-catenin occurred concomitantly in response to EGFR signaling in A549 and H23 lung adenocarcinoma cells. This correlation is in agreement with a previous report demonstrating that $\beta$-catenin up-regulates Nanog expression in embryonic stem cells [31]. We proposed that Nanog contributes to tumorigenesis and represents an important prognostic marker of poor prognosis in patients with NSCLC.

Taken together, we showed that negative expression of membranous $\beta$-catenin correlated with a shorter survival time than the normal expression level of the protein. However, high expression of nuclear $\beta$-catenin was strongly associated with poor prognosis and was an independent prognosticator for OS. We further found that NSCLC cells frequently exhibited nuclear Nanog protein abundance that is significantly correlated with nuclear $\beta$-catenin expression and poor prognosis. Furthermore, results from IHC staining with established lung cancer cell lines revealed that increased expression of Nanog and nuclear translocation of $\beta$-catenin occurred concomitantly in response to EGFR signaling. In conclusion, we propose that evaluation of subcellular localization of $\beta$-catenin and Nanog expression is of clinical significance for patients with NSCLC.

\section{Competing interests}

The authors declare no conflict of interest.

\section{Authors' contribution}

XQL carried out the cases collection, immunohistochemical staining and western blot analysis. XLY and GZ conducted immunofluorescent staining SPW and XBD performed the statistical analysis. SJX constructed the tissue microarrays. QZL participated in the design of the study. GHX and KTY designed and conceived of the study, XQL helped to draft the manuscript. $\mathrm{GHX}$ wrote the manuscript. All authors have read and approved the final manuscript.

\section{Acknowledgements}

This study was supported by the National Basic Research Program of China (973 Program, No. 2010CB529401) and Natural Science Foundation of China (No.81072205)

\section{Author details}

${ }^{1}$ Cancer Institute, Southern Medical University, 1023 Shatai Road South, Guangzhou 510515, China. ${ }^{2}$ Hospital of Guilin Medical University, Guilin, China.

Received: 24 December 2012 Accepted: 16 April 2013

Published: 6 May 2013

\section{References}

1. Jemal A, Siegel R, Xu J, Ward E: Cancer statistics, 2010. CA Canc J Clin 2010, 60(5):277-300.

2. Brambilla E, Travis WD, Colby TV, Corrin B, Shimosato Y: The new World Health Organization classification of lung tumours. Eur Respir J 2001, 18(6):1059-1068.

3. Carney DN, Hansen $\mathrm{HH}$ : Non-small-cell lung cancer-stalemate or progress? N Engl J Med 2000, 343(17):1261-1262.

4. Goffin J, Lacchetti C, Ellis PM, Ung YC, Evans WK: First-line systemic chemotherapy in the treatment of advanced non-small cell lung cancer: a systematic review. J Thorac Oncol 2010, 5(2):260-274.

5. Fuchs SY, Ougolkov AV, Spiegelman VS, Minamoto T: Oncogenic beta-catenin signaling networks in colorectal cancer. Cell Cycle 2005 4(11):1522-1539.

6. Kemler R, Ozawa M: Uvomorulin-catenin complex: cytoplasmic anchorage of a Ca2+-dependent cell adhesion molecule. Bioessays 1989, 11(4):88-91.

7. Konigshoff $M$, Eickelberg O: WNT signaling in lung disease: a failure or a regeneration signal? Am J Respir Cell Mol Biol 2010, 42(1):21-31.

8. Yu J, Vodyanik MA, Smuga-Otto K, Antosiewicz-Bourget J, Frane JL, Tian S, Nie J, Jonsdottir GA, Ruotti V, Stewart R, et al: Induced pluripotent stem cell lines derived from human somatic cells. Science 2007, 318(5858):1917-1920.

9. Boyer LA, Lee TI, Cole MF, Johnstone SE, Levine SS, Zucker JP, Guenther MG, Kumar RM, Murray HL, Jenner RG, et al: Core transcriptional regulatory circuitry in human embryonic stem cells. Cell 2005, 122(6):947-956.

10. Wang J, Rao S, Chu J, Shen X, Levasseur DN, Theunissen TW, Orkin SH: A protein interaction network for pluripotency of embryonic stem cells. Nature 2006, 444(7117):364-368.

11. Hu L, McArthur C, Jaffe RB: Ovarian cancer stem-like side-population cells are tumourigenic and chemoresistant. Br J Canc 2010, 102(8):1276-1283.

12. Wen J, Park JY, Park KH, Chung HW, Bang S, Park SW, Song SY: Oct4 and Nanog expression is associated with early stages of pancreatic carcinogenesis. Pancreas 2010, 39(5):622-626.

13. Chiou SH, Wang ML, Chou YT, Chen CJ, Hong CF, Hsieh WJ, Chang HT, Chen YS, Lin TW, Hsu HS, et al: Coexpression of Oct4 and Nanog enhances malignancy in lung adenocarcinoma by inducing cancer stem cell-like properties and epithelial-mesenchymal transdifferentiation. Canc Res 2010, 70(24):10433-10444.

14. Wray J, Hartmann C: WNTing embryonic stem cells. Trends Cell Bio/ 2012, 22(3):159-168.

15. Ma L, Zhang G, Miao XB, Deng XB, Wu Y, Liu Y, Jin ZR, Li XQ, Liu QZ, Sun DX, et al: Cancer Stem-like Cell Properties are Regulated by EGFR/AKT/betacatenin Signaling and Preferentially Inhibited by Gefitinib in Nasopharyngeal Carcinoma. FEBS J 2013.

16. Li ZH, Qiu MZ, Zeng ZL, Luo HY, Wu WJ, Wang F, Wang ZQ, Zhang DS, Li YH, $\mathrm{Xu} \mathrm{RH}$ : Copper-transporting P-type adenosine triphosphatase (ATP7A) is associated with platinum-resistance in non-small cell lung cancer (NSCLC). J Trans/ Med 2012, 10:21

17. Miao LJ, Huang SF, Sun ZT, Gao ZY, Zhang RX, Liu Y, Wang J: MiR-449c targets c-Myc and inhibits NSCLC cell progression. FEBS Lett 2013.

18. Wiznerowicz M, Trono D: Conditional suppression of cellular genes: lentivirus vector-mediated drug-inducible RNA interference. J Virol 2003 77(16):8957-8961.

19. Normanno N, De Luca A, Bianco C, Strizzi L, Mancino M, Maiello MR, Carotenuto A, De Feo G, Caponigro F, Salomon DS: Epidermal growth factor receptor (EGFR) signaling in cancer. Gene 2006, 366(1):2-16.

20. Bunn PA Jr, Franklin W: Epidermal growth factor receptor expression, signal pathway, and inhibitors in non-small cell lung cancer. Semin Oncol 2002, 29(5 Suppl 14):38-44 
21. Lopez-Knowles E, Zardawi SJ, McNeil CM, Millar EK, Crea P, Musgrove EA, Sutherland RL, O'Toole SA: Cytoplasmic localization of beta-catenin is a marker of poor outcome in breast cancer patients. Canc Epidemiol Biomarkers Prev 2010, 19(1):301-309.

22. Yu B, Yang X, Xu Y, Yao G, Shu H, Lin B, Hood L, Wang H, Yang S, Gu J, et al: Elevated expression of DKK1 is associated with cytoplasmic/nuclear beta-catenin accumulation and poor prognosis in hepatocellular carcinomas. J Hepatol 2009, 50(5):948-957.

23. Baldus SE, Monig SP, Huxel S, Landsberg S, Hanisch FG, Engelmann K, Schneider PM, Thiele J, Holscher AH, Dienes HP: MUC1 and nuclear beta-catenin are coexpressed at the invasion front of colorectal carcinomas and are both correlated with tumor prognosis. Clin Canc Res 2004, 10(8):2790-2796.

24. Bremnes RM, Veve R, Gabrielson E, Hirsch FR, Baron A, Bemis L, Gemmill RM, Drabkin HA, Franklin WA: High-throughput tissue microarray analysis used to evaluate biology and prognostic significance of the E-cadherin pathway in non-small-cell lung cancer. J Clin Oncol 2002, 20(10):2417-2428.

25. Xu HT, Wang L, Lin D, Liu Y, Liu N, Yuan XM, Wang EH: Abnormal beta-catenin and reduced axin expression are associated with poor differentiation and progression in non-small cell lung cancer. Am J Clin Pathol 2006, 125(4):534-541.

26. Chiu CG, Chan SK, Fang ZA, Masoudi H, Wood-Baker R, Jones SJ, Gilks B, Laskin J, Wiseman SM: Beta-catenin expression is prognostic of improved non-small cell lung cancer survival. Am J Surg 2012, 203(5):654-659.

27. Nguyen DX, Chiang AC, Zhang XH, Kim JY, Kris MG, Ladanyi M, Gerald WL, Massague J: WNT/TCF signaling through LEF1 and HOXB9 mediates lung adenocarcinoma metastasis. Cell 2009, 138(1):51-62.

28. Pirinen RT, Hirvikoski P, Johansson RT, Hollmén S, Kosma V-M: Reduced expression of a-catenin, $\beta$-catenin, and $\gamma$-catenin is associated with high cell proliferative activity and poor differentiation in non-small cell lung cancer. J Clin Pathol 2001, 54(5):391-395.

29. Kase S, Sugio K, Yamazaki K, Okamoto T, Yano T, Sugimachi K: Expression of E-cadherin and beta-catenin in human non-small cell lung cancer and the clinical significance. Clin Canc Res 2000, 6(12):4789-4796.

30. Hommura F, Furuuchi K, Yamazaki K, Ogura S, Kinoshita I, Shimizu M, Moriuchi T, Katoh H, Nishimura M, Dosaka-Akita H: Increased expression of beta-catenin predicts better prognosis in nonsmall cell lung carcinomas. Cancer 2002, 94(3):752-758.

31. Takao Y, Yokota T, Koide H: Beta-catenin up-regulates Nanog expression through interaction with Oct-3/4 in embryonic stem cells. Biochem Biophys Res Commun 2007, 353(3):699-705.

doi:10.1186/1479-5876-11-114

Cite this article as: Li et al:: Nuclear $\beta$-catenin accumulation is associated with increased expression of Nanog protein and predicts poor prognosis of non-small cell lung cancer. Journal of Translational Medicine 2013 11:114

\section{Submit your next manuscript to BioMed Central and take full advantage of:}

- Convenient online submission

- Thorough peer review

- No space constraints or color figure charges

- Immediate publication on acceptance

- Inclusion in PubMed, CAS, Scopus and Google Scholar

- Research which is freely available for redistribution 